\title{
PENINGKATAN EFISIENSI PEMISAHAN RADIOISOTOP TERBIUM-161 BERBASIS KROMATOGRAFI KOLOM UNTUK APLIKASI TERAPI KANKER
}

\author{
Azmairit Aziz \\ Pusat Sains dan Teknologi Nuklir Terapan - Badan Tegaga Nuklir Nasional \\ Jl. Tamansari No. 71 Bandung, 40132 \\ aaziz@batan.go.id \\ Diterima: 14-07-2017 \\ Diterima dalam bentuk revisi: 30-08-2017 \\ Disetujui: 19-09-2017
}

\begin{abstract}
ABSTRAK
PENINGKATAN EFISIENSI PEMISAHAN RADIOISOTOP TERBIUM-161 BERBASIS KROMATOGRAFI KOLOM UNTUK APLIKASI TERAPI KANKER. Angka kematian akibat kanker terus meningkat setiap tahun. Endoradioterapi, teknik nuklir menggunakan radionuklida untuk terapi kanker, merupakan teknik yang kompetitif dalam menangani penyakit kanker. Terbium-161 $\left({ }^{161} \mathrm{~Tb}\right)$ adalah radiolantanida pemancar- $\beta$ - lemah yang potensial untuk terapi kanker ukuran kecil. Pada penelitian sebelumnya telah diperoleh pemisahan ${ }^{161} \mathrm{~Tb}$ dari hasil iradiasi bahan sasaran $\mathrm{Gd}_{2} \mathrm{O}_{3}$ diperkaya isotop ${ }^{160} \mathrm{Gd}$ dengan metode kromatografi ekstraksi. Akan tetapi yield ${ }^{161} \mathrm{~Tb}$ yang diperoleh masih rendah, yaitu 93\%. Pada penelitian ini telah dilakukan upaya untuk meningkatkan efisiensi pemisahan ${ }^{161} \mathrm{~Tb}$ dari hasil iradiasi bahan sasaran $\mathrm{Gd}_{2} \mathrm{O}_{3}$ diperkaya isotop ${ }^{160} \mathrm{Gd}$ menggunakan berbagai ukuran dan jenis resin $\mathrm{Ln}$ yaitu kolom resin Ln yang memiliki ukuran partikel $20-50,50-100$ dan $100-150 \mu \mathrm{m}$ serta catridge resin Ln, Ln2 dan Ln3 dengan ukuran partikel $50-100 \mu \mathrm{m}$ sebagai fase diam. Sebagai fase gerak digunakan larutan $\mathrm{HNO}_{3} \quad 0,8 \mathrm{~N}$ dan $3 \mathrm{~N}$ masing-masing untuk memisahkan isotop gadolinium dan terbium. Pada penelitian ini diperoleh peningkatan efisiensi pemisahan ${ }^{161} \mathrm{~Tb}$ menggunakan catridge resin Ln dengan ukuran partikel 50 - $100 \mu \mathrm{m}$ (ditandem 2 buah) dengan yield mencapai $100 \%$ dan Gd recovery sebesar $97,65 \pm 0,2 \%$. Radioisotop ${ }^{161} \mathrm{~Tb}$ hasil pemisahan memiliki kemurnian radionuklida $99,98 \pm 0,01 \%$. Sediaan radioisotop ${ }^{161} \mathrm{TbCl}_{3}$ yang dihasilkan memiliki kemurnian radiokimia sebesar $99,92 \pm 0,2 \%$.
\end{abstract}

Kata kunci: terbium-161, diperkaya, kromatografi kolom, kanker, endoradioterapi.

\section{ABSTRACT}

THE EFFICIENCY OF SEPARATION TERBIUM-161 IMPROVEMENT BASED ON COLUMN CHROMATOGRAPHY FOR CANCER THERAPY APPLICATIONS. The mortality rate due to cancer has been increased every year. Endoradiotherapy, nuclear technique using radionuclide for cancer therapy, is a competitive technique in cancer treatment. Terbium-161 $\left({ }^{161} \mathrm{~Tb}\right)$ is a low beta emitter of radiolanthanide which is potential for small cancer therapy. In the previous study, separation of ${ }^{161} \mathrm{~Tb}$ from irradiated ${ }^{160} \mathrm{Gd}$ enriched of $\mathrm{Gd}_{2} \mathrm{O}_{3}$ target has been obtained based on the extraction chromatography method. However, the yield of ${ }^{161} \mathrm{~Tb}$ obtained was still low, i.e 93\%. In this study, an effort has been conducted in order to increase the separation efficiency of ${ }^{161} \mathrm{~Tb}$ from irradiated ${ }^{160} \mathrm{Gd}$ enriched of $\mathrm{Gd}_{2} \mathrm{O}_{3}$ target using various sizes and types of $L n$ resin i.e $L n$ resin column with particle size of $20-50,50-100$ and $100-150$ $\mu \mathrm{m}$ as well as various types of Ln resin cartidge (Ln, Ln2 and Ln3 resin catridge) with particle size of $50-100 \mu \mathrm{m}$ as the stationary phase. Whereas a mobile phase of $0.8 \mathrm{~N}$ and $3 \mathrm{~N} \mathrm{HNO}_{3}$ solutions were used to separate gadolinium and terbium isotope, respectively. Based on this study, the improvement for efficiency of separation ${ }^{161} \mathrm{~Tb}$ were obtained using $\mathrm{Ln}$ resin catridge $50-100 \mu \mathrm{m}$ particle size (double tandem column) with the yield up to $100 \%$ and Gd recovery of $97.65 \pm 0.2 \%$. The separated ${ }^{161} \mathrm{~Tb}$ was obtained with radionuclide purity of $99.98 \pm 0.01 \%$. ${ }^{161} \mathrm{TbCl}_{3}$ radioisotope solution has a radiochemical purity of $99.92 \pm 0.2 \%$.

Keywords: terbium-161, enriched, column chromatography, cancer, endoradiotherapy. 


\section{PENDAHULUAN}

Penderita kanker terus mengalami peningkatan setiap tahun, termasuk di Indonesia. Kanker merupakan salah satu penyebab utama kematian di seluruh dunia $(1,2)$. Terapi kanker dengan cara operasi, kemoterapi dan radiasi eksternal merupakan metode terapi utama yang sudah digunakan selama ini untuk mengatasi kanker. Kemoterapi memiliki selektivitas terhadap tumor sangat rendah, sehingga sistemik kemoterapi sering menjadi terbatas karena efek samping serius yang ditimbulkannya terhadap sel normal. Konsekuensi dari efek samping ini adalah penggunaan dosis suboptimal yang dapat menyebabkan kegagalan terapeutik dan juga resistensi terhadap obat (3).

Teknik nuklir menggunakan radionuklida merupakan teknik yang kompetitif dalam mengatasi kanker. Terapi kanker menggunakan radionuklida ${ }^{131}$ I telah berhasil diaplikasikan untuk mengatasi kanker tiroid selama lebih dari 65 tahun (4). Teknik nuklir untuk terapi kanker yang dikenal dengan istilah endoradioterapi (targeted radionuclide therapy) sangat menjanjikan untuk mengatasi permasalahan kanker ini. Berbagai jenis tumor-targeted biomolecules yaitu peptida, antibodi dan fragmen antibodi telah digunakan untuk ditandai dengan radionuklida yang sesuai, sehingga dihasilkan radiofarmaka yang secara selektif mengirimkan dosis terapi ke jaringan target (3,5-7).

Radionuklida/radioisotop merupakan prekursor dalam pembuatan suatu radiofarmaka. Pemilihan radionuklida dengan tepat sangat menjanjikan untuk meningkatkan kemampuan terapi dengan cara endoradioterapi (8). Radionuklida yang dapat digunakan untuk terapi merupakan pemancar partikel alfa, beta dan elektron Auger $(1,9)$. Elektron berenergi rendah, seperti elektron Auger dan elektron konversi internal dapat menimbulkan dampak sitotoksisitas yang sangat tinggi pada jaringan. Hal ini disebabkan jarak tembusnya yang relatif pendek pada jaringan, sehingga mengakibatkan kerusakan lokal yang tinggi. Elektron Auger dan elektron konversi internal sangat menjanjikan untuk peningkatan keberhasilan dalam endoradioterapi (10).

Terbium-161 ( $\left.{ }^{161} \mathrm{~Tb}\right)$ merupakan radiolantanida pemancar- $\beta^{-}$lemah $\left(E_{\beta}{ }^{-}\right.$rata-rata $=$ $0,150 \mathrm{MeV}, \mathrm{t}_{1 / 2}=6,9$ hari) yang mirip dengan radiolantanida ${ }^{177} \mathrm{Lu}$ dari sifat nuklirnya $\left(E_{\beta}{ }^{-}\right.$rata-rata $=0,140 \mathrm{MeV}, t_{1 / 2}=6,7$ hari), yaitu baik dari segi waktu paro dan energi beta juga dari sifat kimianya (7). Sebagaimana ${ }^{177} \mathrm{Lu}$, radioisotop ${ }^{161} \mathrm{~Tb}$ juga memancarkan foton berenergi rendah $(\mathrm{EY}=45 \mathrm{keV})$ yang berguna untuk pencitraan menggunakan kamera gamma $(7,11)$.

Di samping waktu paro dan energi beta yang dimilikinya yang sangat cocok untuk keperluan terapi, ${ }^{161} \mathrm{~Tb}$ ternyata memiliki sifat nuklir yang lebih unggul untuk terapi di banding ${ }^{177} \mathrm{Lu}$ karena selain merupakan pemancar partikel $\beta-{ }^{161} \mathrm{~Tb}$ juga melepaskan elektron Auger dan elektron konversi internal yang dapat mengakibatkan radiositotoksisitas yang lebih besar pada jaringan. Berdasarkan kelebihan sifat nuklir yang dimilikinya, maka ${ }^{161} \mathrm{~Tb}$ akan memberikan hasil terapi yang lebih baik dibanding ${ }^{177} \mathrm{Lu}(7,8)$. 
Radioisotop ${ }^{161} \mathrm{~Tb}$ dapat dibuat dalam bentuk bebas pengemban (carrier free), sehingga memungkinkan diperoleh sediaan radioisotop ${ }^{161} \mathrm{~Tb}$ dengan aktivitas jenis tinggi yang dapat digunakan dalam penandaan biomolekul sebagai radiofarmaka spesifik target untuk terapi kanker. Hasil evaluasi dosimetri terhadap efisiensi terapeutik radiolantanida pemancar elektron menunjukkan bahwa radioisotop ${ }^{161} \mathrm{~Tb}$ dapat mentransfer energinya 2 sampai 3 kali lebih tinggi dibanding ${ }^{177} \mathrm{Lu}$ karena ${ }^{161} \mathrm{~Tb}$ memancarkan elektron konversi dan elektron Auger yang tinggi (7). Oleh karena itu, maka ${ }^{161} \mathrm{~Tb}$ dapat digunakan sebagai alternatif radioisotop ${ }^{177} \mathrm{Lu}$ untuk terapi tumor/kanker ukuran kecil $(7,12)$. Radioisotop ${ }^{161} \mathrm{~Tb}$ bebas pengemban (carrier-free) dapat dibuat dengan cara tidak langsung melalui reaksi inti $(n, y)$ di reaktor nuklir dengan menggunakan bahan sasaran isotop gadolinium-160 ( ${ }^{160} \mathrm{Gd}$ ) menghasilkan radioisotop induk ${ }^{161} \mathrm{Gd}$ yang selanjutnya meluruh menjadi radioisotop anak ${ }^{161} \mathrm{~Tb}$ $(7,10)$.

Pada penelitian sebelumnya telah dilakukan studi awal pemisahan radioisotop ${ }^{161} \mathrm{~Tb}$ hasil iradiasi bahan sasaran $\mathrm{Gd}_{2} \mathrm{O}_{3}$ alam menggunakan 1 gram resin Ln (13), yang mengacu pada penelitian yang dikemukakan oleh Guzman dengan informasi data kondisi pemisahan yang sangat terbatas (14). Untuk memperoleh radioisotop ${ }^{161} \mathrm{~Tb}$ dengan aktivitas jenis tinggi, maka dibutuhkan bahan sasaran $\mathrm{Gd}_{2} \mathrm{O}_{3}$ diperkaya isotop ${ }^{160} \mathrm{Gd}$. Kemudian penelitian dilanjutkan untuk optimasi hasil menggunakan bahan sasaran $\mathrm{Gd}_{2} \mathrm{O}_{3}$ diperkaya $\left({ }^{160} \mathrm{Gd} \quad 98,2 \%\right)$ dengan cara memvariasi jumlah resin Ln dan diperoleh kondisi optimum hasil pemisahan radioisotop ${ }^{161} \mathrm{~Tb}$ menggunakan 2 gram resin Ln dengan yield sekitar 93\% (15). Dalam upaya peningkatan efisiensi pemisahan radioisotop ${ }^{161} \mathrm{~Tb}$ berbasis kromatografi ekstraksi ini, maka pada penelitian ini dilanjutkan dengan menggunakan berbagai ukuran partikel dan jenis resin Ln untuk pemisahan radioisotop ${ }^{161} \mathrm{~Tb}$ hasil iradiasi bahan sasaran $\mathrm{Gd}_{2} \mathrm{O}_{3}$ diperkaya isotop ${ }^{160} \mathrm{Gd}(98,4 \%)$.

Tujuan dari penelitian ini adalah memperoleh data pemisahan radioisotop ${ }^{161} \mathrm{~Tb}$ hasil iradiasi bahan sasaran gadolinium oksida diperkaya isotop ${ }^{160} \mathrm{Gd}$ $(98,4 \%)$ menggunakan berbagai ukuran partikel dan jenis resin Ln. Dari penelitian ini diharapkan diperoleh peningkatan efisiensi pemisahan radioisotop ${ }^{161} \mathrm{~Tb}$.

\section{TATA KERJA}

\subsection{Bahan dan Peralatan}

Bahan utama yang digunakan pada penelitian ini adalah gadolinium oksida $\left(\mathrm{Gd}_{2} \mathrm{O}_{3}\right)$ diperkaya isotop ${ }^{160} \mathrm{Gd} \quad 98,4 \%$ buatan Trace Science, resin Ln (=HDEHP) dengan ukuran partikel $20-50,50-100$ dan 100 - $150 \mu \mathrm{m}$ buatan Eichrom, kolom catridge resin $\mathrm{Ln}(=\mathrm{HDEHP}) 2 \mathrm{~mL}$, catridge resin Ln2 (=HEH[EHP]) $2 \mathrm{~mL}$ dan catridge resin Ln3 (=H[TMPeP]) $2 \mathrm{~mL}$ masing-masing dengan ukuran partikel $50-100 \mu \mathrm{m}$ buatan Eichrom, asam nitrat, asam klorida dan asam asetat buatan E.Merck, serta akuabides steril buatan IPHA. Bahan penunjang yang digunakan adalah kertas 
kromatografi Whatman $3 \mathrm{MM}$ dan kertas indikator $\mathrm{pH}$. Peralatan yang digunakan adalah alat pencacah $\mathrm{y}$ saluran tunggal (SCA) dengan detektor Nal-TI (Ortec), alat spektrometer $\mathrm{Y}$ dengan detektor HP-Ge yang dilengkapi dengan multichannel analyzer (Canberra) yang dikalibrasi menggunakan sumber standar campuran radionuklida pemancar sinar- $\gamma\left({ }^{241} \mathrm{Am},{ }^{137} \mathrm{Cs}\right.$ dan ${ }^{60} \mathrm{Co}$ ) dengan $\mathrm{E}_{\gamma}$ mulai dari $26,34 \mathrm{keV}$ $\left(E_{\gamma}\right.$ radionuklida $\left.{ }^{241} \mathrm{Am}\right)$ sampai $1332 \mathrm{keV}$ $\left(E_{\gamma}\right.$ radionuklida $\left.{ }^{60} \mathrm{Co}\right)$, neraca analitik (Mettler Toledo), alat pemanas dan pengaduk magnetik (Thermolyne), kolom gelas (diameter $1,5 \mathrm{~cm}$, panjang $15 \mathrm{~cm}$ ), pipet mikro (Thermo Scientific), seperangkat alat kromatografi kertas dan peralatan gelas.

\subsection{Penyiapan bahan sasaran untuk diiradiasi}

Sebanyak $5 \mathrm{mg}$ bahan sasaran gadolinium oksida $\left(\mathrm{Gd}_{2} \mathrm{O}_{3}\right)$ diperkaya isotop ${ }^{160} \mathrm{Gd} 98,4 \%$ dimasukkan ke dalam tabung kuarsa, lalu ditutup dengan cara pengelasan alat gelas. Setelah lolos uji kebocoran, tabung berisi bahan sasaran tersebut dimasukkan ke dalam inner capsule aluminium dan ditutup lagi dengan cara pengelasan. Setelah lolos uji kebocoran, inner capsule dimasukkan ke dalam outer capsule aluminium.

\subsection{Iradiasi bahan sasaran $\mathrm{Gd}_{2} \mathrm{O}$}

Bahan sasaran $\mathrm{Gd}_{2} \mathrm{O}_{3}$ yang telah disiapkan dalam capsule aluminium diiradiasi di central irradiation position (CIP) RSG-G.A. Siwabessy selama \pm 4 hari pada fluks neutron termal $\sim 10^{14} \mathrm{n} \cdot \mathrm{cm}^{-2} \cdot \mathrm{s}^{-1}$. Setelah selesai iradiasi, bahan sasaran hasil iradiasi dikeluarkan dari teras reaktor. Kemudian dilakukan proses pendinginan (cooling) selama \pm 1 hari.

\subsection{Pelarutan bahan sasaran hasil iradiasi}

Proses pelarutan bahan sasaran hasil iradiasi dilakukan di dalam boks proses radioisotop yang dilengkapi dengan penahan (shielding) untuk radiasi pemancar- $\beta$ - dan sinar- $\gamma$. Bahan sasaran $\mathrm{Gd}_{2} \mathrm{O}_{3}$ hasil iradiasi dimasukkan ke dalam vial gelas berukuran $50 \mathrm{~mL}$. Kemudian dilarutkan dalam $3 \mathrm{~mL}$ larutan $\mathrm{HCl} 2 \mathrm{~N}$ sambil dipanaskan perlahan-lahan di atas alat pemanas dan pengaduk magnetik sampai larut sempurna. Kemudian larutan dikisatkan sampai hampir kering dan dilarutkan kembali dalam $2 \mathrm{~mL}$ akuabides steril.

\subsection{Penyiapan kolom}

Pada penelitian ini digunakan resin Ln (HDEHP = asam di(2-etilheksil ortofosfat) dengan ukuran partikel $20-50,50-100$ dan 100 - $150 \mu \mathrm{m}$ serta berbagai jenis resin lantanida masing-masing dengan ukuran partikel $50-100 \mu \mathrm{m}$ sebagai fase diam, yaitu resin Ln (HDEHP = asam di(2-etilheksil ortofosfat) dalam bentuk kolom gelas dan catridge, serta resin Ln2 (HEH[EHP] = asam 2-etilheksil 2-etilheksilfosfat) dan resin Ln3 $(\mathrm{H}[\mathrm{TMPeP}]=$ asam $\mathrm{di}(2,4,4$-trimetil pentilfosfat) dalam bentuk kolom catridge sebagai upaya untuk memperoleh peningkatan efisiensi pemisahan radioisotop ${ }^{161} \mathrm{~Tb}$ dari bahan sasaran $\mathrm{Gd}_{2} \mathrm{O}_{3}$ hasil iradiasi. Penyiapan kolom dalam bentuk kolom gelas, yaitu sejumlah resin Ln 
ditimbang dan direndam dalam larutan asam nitrat $0,15 \mathrm{~N}$ selama \pm 1 jam. Kemudian dimasukkan ke dalam kolom gelas yang telah diberi glass wool pada bagian dasarnya. Pada bagian atas resin dilapisi lagi dengan glass wool. Kemudian kolom dibilas dengan larutan asam nitrat $0,15 \mathrm{~N}$ sampai jernih dan tingkat keasaman $(\mathrm{pH})$ larutan tetesan pada ujung kolom gelas sama dengan $\mathrm{pH}$ larutan asam nitrat $0,15 \mathrm{~N}$. Sedangkan penyiapan kolom dalam bentuk catridge, yaitu resin dalam catridge dibilas dengan larutan asam nitrat $0,15 \mathrm{~N}$ sampai $\mathrm{pH}$ larutan tetesan pada ujung kolom catridge sama dengan $\mathrm{pH}$ larutan asam nitrat $0,15 \mathrm{~N}$. Setelah itu, kolom dan catridge dibiarkan semalaman dan dijaga tetap terendam dalam larutan asam nitrat $0,15 \mathrm{~N}$.

\subsection{Pemisahan radioisotop ${ }^{161} \mathrm{~Tb}$ dari matriks Gd/Tb}

Sebanyak $100-300 \mu \mathrm{L}(2-5 \mathrm{mCi})$ larutan ${ }^{161} \mathrm{~Tb}$ yang mengandung campuran radioisotop $\mathrm{Gd} / \mathrm{Tb}$ hasil iradiasi bahan sasaran $\mathrm{Gd}_{2} \mathrm{O}_{3}$ diperkaya isotop ${ }^{160} \mathrm{Gd}$ $(98,4 \%)$ dimasukkan dengan hati hati ke dalam kolom. Kemudian kolom dielusi berturut-turut menggunakan larutan $\mathrm{HNO}_{3}$ $0,15 \mathrm{~N}$ (fraksi 1-6), larutan $\mathrm{HNO}_{3} 0,8 \mathrm{~N}$ (fraksi 7-28) dan $\mathrm{HNO}_{3} 3 \mathrm{~N}$ (fraksi 29-50). Setiap 1 $\mathrm{mL}$ eluat ditampung di dalam vial gelas.

\subsection{Penentuan kemurnian radionuklida dan radioaktivitas hasil pemisahan}

Setiap $1 \mathrm{~mL}$ eluat dianalisis untuk mengetahui radioaktivitas dan jenis radionuklida yang terkandung di dalamnya yaitu dengan cara dicacah menggunakan alat spektrometer-y dengan detektor HP-Ge yang telah dilengkapi dengan multichannel analyzer (MCA). Selanjutnya hasil cacahan dianalisis menggunakan software Genie 2000.

\subsection{Penyiapan larutan radioisotop ${ }^{161} \mathrm{~Tb}$ dalam bentuk senyawa ${ }^{161} \mathrm{TbCl}_{3}$}

Semua eluat yang mengandung fraksi ${ }^{161} \mathrm{~Tb}$ dikumpulkan dan dikisatkan sampai hampir kering untuk menguapkan nitrat yang terkandung di dalam larutan. Kemudian residu dilarutkan kembali dalam larutan $\mathrm{HCl}$ $0,1 \mathrm{~N}$ untuk menghasilkan larutan radioisotop ${ }^{161} \mathrm{~Tb}$ dalam bentuk senyawa kimia ${ }^{161} \mathrm{TbCl}_{3}$.

\subsection{Penentuan kemurnian radiokimia larutan radioisotop ${ }^{161} \mathrm{TbCl}_{3}$}

Produk akhir sediaan radioisotop ${ }^{161} \mathrm{TbCl}_{3}$ ditentukan kemurnian radiokimianya dengan metode kromatografi kertas menggunakan kertas kromatografi Whatman $3 \mathrm{MM}(2 \times 10 \mathrm{~cm})$ sebagai fase diam serta larutan asam asetat $50 \%$ sebagai fase gerak. Kemudian kromatogram dikeringkan, dipotong-potong sepanjang $1 \mathrm{~cm}$ dan dicacah menggunakan alat pencacah $\mathrm{Y}$ saluran tunggal dengan detektor $\mathrm{Nal}-\mathrm{TI}$.

\section{HASIL DAN PEMBAHASAN}

Radioisotop ${ }^{161} \mathrm{~Tb}$ dapat diproduksi di reaktor nuklir secara tidak langsung melalui reaksi inti ${ }^{160} \mathrm{Gd}(\mathrm{n}, \gamma)^{161} \mathrm{Gd} \stackrel{\beta-}{\longrightarrow}{ }^{161} \mathrm{~Tb}$. Hasil iradiasi di reaktor nuklir terhadap bahan sasaran $\mathrm{Gd}_{2} \mathrm{O}_{3}$ diperkaya isotop ${ }^{160} \mathrm{Gd}$ $98,4 \%$, setelah dianalisis menggunakan spektrometer- $\gamma$ tidak terlihat adanya keberadaan radionuklida induk ${ }^{161} \mathrm{Gd}$ seperti ditunjukkan oleh spektrum sinar-y pada 
Gambar 1. Hal ini disebabkan radionuklida ${ }^{161} \mathrm{Gd}$ memiliki waktu paro yang sangat singkat yaitu selama 3,66 menit, sehingga dengan pendinginan selama \pm 1 hari sebelum proses pemisahan maka radionuklida induk $\left({ }^{161} \mathrm{Gd}\right)$ telah meluruh semuanya menjadi radionuklida anak (161 Tb).

Pada spektrum sinar-y terlihat bahwa selain radionuklida ${ }^{161} \mathrm{~Tb}$ sebagai radionuklida yang diharapkan, juga terdapat beberapa radionuklida lain sebagai pengotor radionuklida yaitu ${ }^{153} \mathrm{Gd}$ dan ${ }^{160} \mathrm{~Tb}$. Hal ini dibuktikan dengan munculnya berbagai puncak energi- $\mathrm{Y}\left(\mathrm{E}_{\mathrm{Y}}\right)$ yang dimiliki kedua radionuklida tersebut pada spektrum sinar- $\gamma$ yang diperoleh. Pengotor radionuklida ${ }^{160} \mathrm{~Tb}$ merupakan hasil reaksi inti ${ }^{159} \mathrm{~Tb}(\mathrm{n}, \mathrm{\gamma})^{160} \mathrm{~Tb}$ dari pengotor isotop ${ }^{159} \mathrm{~Tb}$ yang terdapat di dalam bahan sasaran (10).

Radionuklida ${ }^{153} \mathrm{Gd}$ dan ${ }^{160} \mathrm{~Tb}$ memiliki waktu paro $\left(\mathrm{t}_{1 / 2}\right)$ yang cukup panjang yaitu masing-masing selama 241,6 dan 72,3 hari, sehingga kedua radionuklida tersebut merupakan pengotor radionuklida utama di dalam larutan radioisotop ${ }^{161} \mathrm{~Tb}$. Persentase kemurnian radionuklida ${ }^{161} \mathrm{~Tb}$ dari 5 kali iradiasi bahan sasaran $\mathrm{Gd}_{2} \mathrm{O}_{3}$ diperkaya isotop ${ }^{160} \mathrm{Gd} 98,4 \%$ diperoleh sebesar 99,82 $\pm 0,01 \%$.

Nilai kemurnian radionuklida ${ }^{161} \mathrm{~Tb}$ dalam matriks $\mathrm{Gd} / \mathrm{Tb}$ yang diperoleh dari hasil iradiasi bahan sasaran $\mathrm{Gd}_{2} \mathrm{O}_{3}$ diperkaya isotop ${ }^{160} \mathrm{Gd} 98,4 \%$ buatan Trace Science ini tidak berbeda secara signifikan dengan hasil iradiasi bahan sasaran $\mathrm{Gd}_{2} \mathrm{O}_{3}$ diperkaya isotop ${ }^{160} \mathrm{Gd} 98,2 \%$ buatan ORNL yang diperoleh pada penelitian sebelumnya dengan nilai kemurnian radionuklida sebesar $99,84 \pm 0,15 \%$ (15).

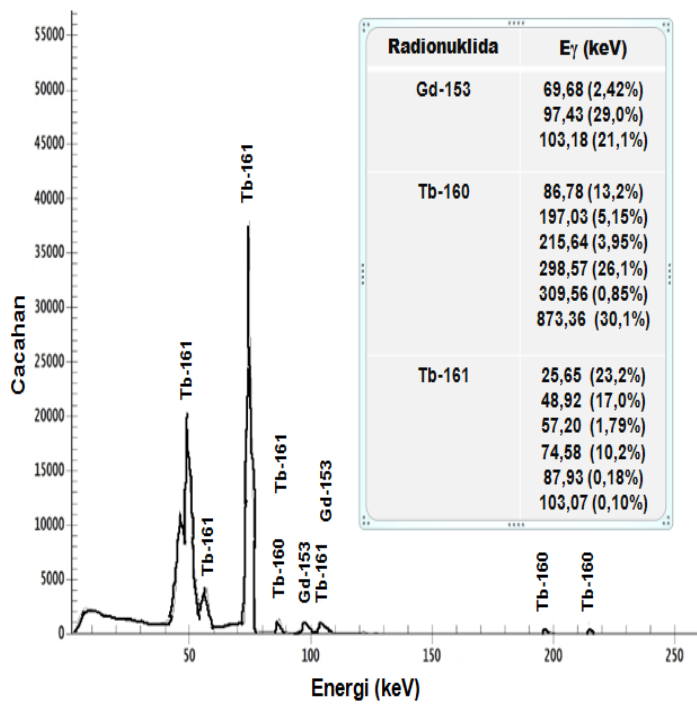

Gambar 1. Spektrum sinar-y larutan radioisotop hasil iradiasi $\mathrm{Gd}_{2} \mathrm{O}_{3}$ diperkaya $\left({ }^{160} \mathrm{Gd}\right.$ $98,4 \%)$.

Pada penelitian sebelumnya juga telah diperoleh data hasil pemisahan ${ }^{161} \mathrm{~Tb}$ dari hasil iradiasi bahan sasaran $\mathrm{Gd}_{2} \mathrm{O}_{3}$ diperkaya ( ${ }^{160} \mathrm{Gd}$ 98,2\%) dengan metode kromatografi ekstraksi menggunakan 2 gram resin Ln. Akan tetapi yield ${ }^{161} \mathrm{~Tb}$ yang diperoleh masih rendah, yaitu sekitar 93\% (15). Untuk itu, pada penelitian lanjutan ini dilakukan upaya peningkatan efisiensi pemisahan radioisotop ${ }^{161} \mathrm{~Tb}$ berbasis kromatografi ekstraksi yaitu dengan menggunakan berbagai ukuran partikel dan jenis resin Ln.

Pada penelitian lanjutan ini diawali dengan proses pemisahan radioisotop ${ }^{161} \mathrm{~Tb}$ dari matriks $\mathrm{Gd} / \mathrm{Tb}$ menggunakan metode kromatografi ekstraksi dalam kolom gelas berisi resin Ln (=HDEHP) masing-masing sebanyak 2 gram yang memiliki ukuran partikel 20 - $50 \mu \mathrm{m}, 50$ - $100 \mu \mathrm{m}$ dan 100 - $150 \mu \mathrm{m}$ sebagai fase diam serta 
larutan asam nitrat $\left(\mathrm{HNO}_{3}\right)$ dengan berbagai konsentrasi sebagai fase gerak.

Tabel 1. Hasil pemisahan ${ }^{161} \mathrm{~Tb}$ menggunakan kolom gelas dengan berbagai ukuran resin Ln.

\begin{tabular}{ccccccc}
\hline No & $\begin{array}{c}\text { Jenis } \\
\text { resin }\end{array}$ & $\begin{array}{c}\text { Ukuran } \\
\text { partikel } \\
(\mu \mathrm{m})\end{array}$ & $\begin{array}{c}\text { Jumlah } \\
\text { resin } \\
(\mathrm{g})\end{array}$ & $\begin{array}{c}\text { Yield }{ }^{161} \mathrm{~Tb} \\
(\%)\end{array}$ & $\begin{array}{c}\text { Gd recovery } \\
(\%)\end{array}$ & $\begin{array}{c}\text { Kemurnian } \\
\text { radionuklida }{ }^{161} \mathrm{~Tb} \\
(\%)\end{array}$ \\
\hline 1 & Ln & $20-50$ & 2 & $91,3 \pm 2,1$ & $85,7 \pm 0,7$ & $99,70 \pm 0,2$ \\
2 & Ln & $50-100$ & 2 & $93,4 \pm 2,5$ & $98,11 \pm 0,9$ & $99,92 \pm 0,1$ \\
3 & Ln & $100-150$ & 2 & $90,3 \pm 1,7$ & $89,5 \pm 0,6$ & $99,62 \pm 0,4$ \\
\hline
\end{tabular}

Dari penelitian ini diperoleh yield pemisahan radioisotop ${ }^{161} \mathrm{~Tb}$ menggunakan berbagai ukuran partikel resin Ln seperti ditunjukkan pada Tabel 1. Pada Tabel 1 terlihat bahwa proses pemisahan menggunakan resin Ln dari ketiga jenis ukuran partikel diperoleh yield pemisahan radioisotop ${ }^{161} \mathrm{~Tb}$ yang cukup tinggi. Akan tetapi yield pemisahan tertinggi diperoleh dengan menggunakan resin Ln dengan ukuran partikel 50-100 $\mu \mathrm{m}$, yaitu sebesar $93,4 \pm 2,5 \%$. Yield yang diperoleh mirip dengan yang telah diperoleh pada penelitian sebelumnya yaitu 93,2 \pm $2,1 \%(15)$.

Dalam produksi radioisotop ${ }^{161} \mathrm{~Tb}$ menggunakan bahan sasaran $\mathrm{Gd}_{2} \mathrm{O}_{3}$ yang diperkaya isotop ${ }^{160} \mathrm{Gd}(98,4 \%)$ karena harga isotop diperkaya sangat mahal, maka bahan sasaran isotop $\mathrm{Gd}$ yang tidak teriradiasi diharapkan dapat diperoleh kembali (recovery). Pada penelitian ini juga diperoleh $\mathrm{Gd}$ recovery (dalam bentuk senyawa $\left.\mathrm{Gd}\left(\mathrm{NO}_{3}\right)_{3}\right)$ hasil pemisahan menggunakan berbagai ukuran partikel resin Ln (Tabel 1). Pada Tabel 1 terlihat bahwa proses pemisahan menggunakan resin Ln dari ketiga jenis ukuran partikel diperoleh $\mathrm{Gd}$ recovery yang tinggi. Akan tetapi, Gd recovery tertinggi diperoleh menggunakan resin Ln dengan ukuran partikel $50-100$ $\mu \mathrm{m}$, yaitu sebesar $98,11 \pm 0,9 \%$. Gd recovery yang diperoleh mirip dengan yang telah diperoleh pada penelitian sebelumnya sebesar $98,11 \pm 1,2 \%$ (15).

Selain yield pemisahan, nilai kemurnian radionuklida juga merupakan faktor yang sangat penting dari hasil pemisahan. Penentuan kemurnian radionuklida dari radioisotop ${ }^{161} \mathrm{~Tb}$ hasil pemisahan dilakukan menggunakan alat spektrometer- $\gamma$ (MCA) dengan detektor HP-Ge. Dari penelitian ini diperoleh nilai kemurnian radionuklida dari radioisotop ${ }^{161} \mathrm{~Tb}$ hasil pemisahan menggunakan berbagai ukuran partikel resin Ln (Tabel 1). Pada Tabel 1 terlihat bahwa proses pemisahan menggunakan resin Ln dari ketiga jenis ukuran partikel diperoleh nilai kemurnian radionuklida ${ }^{161} \mathrm{~Tb}$ yang tertinggi menggunakan resin Ln dengan ukuran partikel $50-100 \mu \mathrm{m}$, yaitu sebesar 99,92 \pm $0,1 \%$. Kemurnian radionuklida yang diperoleh mirip dengan yang telah diperoleh pada penelitian sebelumnya sebesar $99,92 \pm 0,5 \%$ (15) .

Berdasarkan hasil yang diperoleh pada Tabel 1 menunjukkan bahwa proses pemisahan menggunakan kolom gelas berisi resin Ln sebanyak $2 \mathrm{~g}$ dengan ukuran partikel $50-100 \mu \mathrm{m}$ memiliki kriteria pemisahan yang lebih baik dibanding kedua jenis ukuran partikel resin Ln lainnya, baik dari segi yield pemisahan, Gd recovery maupun kemurnian radionuklida dari 
radioisotop ${ }^{161} \mathrm{~Tb}$ yang dihasilkan. Hal ini disebabkan proses pemisahan menggunakan resin Ln yang mengandung ekstraktan asam di(2-etilheksil)orto fosfat (HDEHP) dengan ukuran partikel yang lebih kecil yaitu 20 - $50 \mu \mathrm{m}$ memiliki porositas yang kecil sehingga luas permukaan resin menjadi lebih besar. Jadi bidang sentuh resin dengan analit akan lebih besar sehingga analit lebih mudah teradsorbsi dalam hal ini juga terekstraksi karena resin Ln merupakan ekstraktan HDEHP dan mengalami kesetimbangan dinamis dalam resin. Akan tetapi karena ukuran resinnya lebih kecil, maka analit sulit untuk terdistribusi ke dalam eluen dan keluar dari kolom pada saat proses elusi menggunakan eluen yang sesuai. Hal sebaliknya terjadi pada proses pemisahan menggunakan resin Ln dengan ukuran partikel lebih besar yaitu $100-150 \mu \mathrm{m}$ yang memiliki porositas lebih besar sehingga analit sulit teradsobsi/ terekstraksi pada resin. Jadi analit akan mudah lolos dan sulit mengalami kesetimbangan dinamis dengan baik dalam resin sehingga pemisahan analit menjadi kurang sempurna.

Pada penelitian ini selanjutnya dilakukan upaya proses pemisahan radioisotop ${ }^{161} \mathrm{~Tb}$ dari matriks $\mathrm{Gd} / \mathrm{Tb}$ dengan metode kromatografi ekstraksi dalam bentuk kolom cartridge dengan menggunakan berbagai jenis kolom catridge resin lantanida, yaitu kolom catridge resin Ln (=HDEHP) 2 $\mathrm{mL}$; kolom catridge resin Ln2 (=HEH[EHP]) $2 \mathrm{~mL}$ dan kolom catridge resin Ln3 $(=\mathrm{H}[\mathrm{TMPeP}]) \quad 2 \mathrm{~mL}$ masing-masing memiliki ukuran partikel $50-100 \mu \mathrm{m}$ sebagai fase diam. Adapun berbagai jenis resin lantanida yang digunakan merupakan turunan dari resin Ln yang memiliki struktur kimia seperti diperlihatkan pada Gambar 2.

Tabel 2. Hasil pemisahan radioisotop ${ }^{161} \mathrm{~Tb}$ menggunakan berbagai jenis catridge resin lantanida masingmasing dengan volume $2 \mathrm{~mL}$ per catridge dan ukuran partikel $50-100 \mu \mathrm{m}$.

\begin{tabular}{ccccccc}
\hline No & Jenis resin & $\begin{array}{c}\text { Ukuran } \\
\text { partikel } \\
(\mu \mathrm{m})\end{array}$ & $\begin{array}{c}\text { Jumlah } \\
\text { catridge } \\
\text { (buah) }\end{array}$ & $\begin{array}{c}\text { Yield }{ }^{161} \mathrm{~Tb} \\
(\%)\end{array}$ & $\begin{array}{c}\text { Gd recovery } \\
(\%)\end{array}$ & $\begin{array}{c}\text { Kemurnian } \\
\text { radionuklida }{ }^{161} \mathrm{~Tb} \\
(\%)\end{array}$ \\
\hline 1 & Catridge Ln & $50-100$ & 1 & $97 \pm 0,4$ & $76,72 \pm 0,6$ & $99,91 \pm 0,02$ \\
2 & Catridge Ln & $50-100$ & 2 & 100 & $97,65 \pm 0,2$ & $99,98 \pm 0,01$ \\
3 & Catridge Ln & $50-100$ & 3 & $98,5 \pm 0,5$ & $82,15 \pm 0,8$ & $99,95 \pm 0,03$ \\
4 & Catridge Ln2 & $50-100$ & 1 & t.t & t.t & $99,81 \pm 0,01$ \\
5 & Catridge Ln2 & $50-100$ & 2 & t.t & t.t & $99,82 \pm 0,01$ \\
6 & Catridge Ln2 & $50-100$ & 3 & t.t & t.t & $99,81 \pm 0,02$ \\
7 & Catridge Ln3 & $50-100$ & 1 & t.t & t.t & $99,82 \pm 0,02$ \\
8 & Catridge Ln3 & $50-100$ & 2 & t.t & t.t & $99,83 \pm 0,01$ \\
9 & Catridge Ln3 & $50-100$ & 3 & t.t & t.t & $99,82 \pm 0,02$ \\
\hline
\end{tabular}

Keterangan: t.t $=$ tidak terpisah, yaitu isotop $\mathrm{Gd}$ dan $\mathrm{Tb}$ hasil elusi tidak dapat dipisahkan.
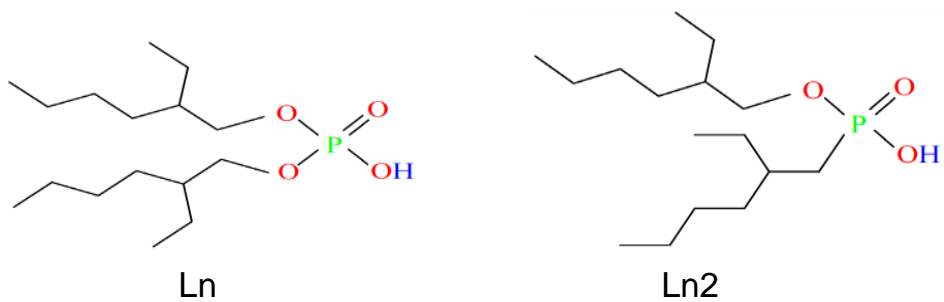

Gambar 2. Berbagai jenis resin lantanida.

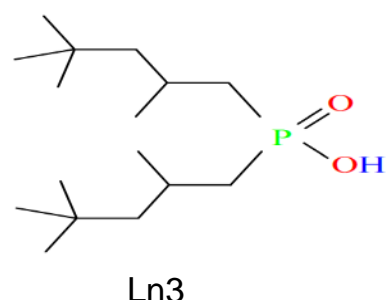

$\operatorname{Ln} 3$ 
Jumlah kolom catridge yang digunakan untuk masing-masing jenis resin divariasikan sebanyak 1, 2 dan 3 buah. Sedangkan sebagai fase gerak digunakan larutan asam nitrat $\left(\mathrm{HNO}_{3}\right)$ dengan berbagai konsentrasi. Dari penelitian ini diperoleh yield pemisahan radioisotop ${ }^{161} \mathrm{~Tb}$ menggunakan berbagai jenis kolom catridge resin lantanida, yaitu catridge resin Ln, Ln2 dan Ln3 masingmasing dengan ukuran partikel $50-100 \mu \mathrm{m}$ seperti ditunjukkan pada Tabel 2. Pada Tabel 2 terlihat bahwa pada proses pemisahan radioisotop ${ }^{161} \mathrm{~Tb}$ dengan menggunakan kolom catridge resin Ln sebanyak 1, 2 dan 3 buah dengan ukuran partikel $50-100 \mu \mathrm{m}$ terjadi pemisahan ${ }^{161} \mathrm{~Tb}$ dari matriks $\mathrm{Gd} / \mathrm{Tb}$ dan diperoleh yield pemisahan radioisotop ${ }^{161} \mathrm{~Tb}$ yang tinggi. Akan tetapi yield tertinggi diperoleh dengan menggunakan kolom catridge resin Ln sebanyak 2 buah (ditandem), yaitu mencapai $100 \%$ (99,9 sampai $100 \%)$. Yield radioisotop ${ }^{161} \mathrm{~Tb}$ yang diperoleh mirip dengan hasil yang diperoleh oleh Guzman dkk dengan yield sebesar $100 \%(16,17)$. Sedangkan pada proses pemisahan radioisotop ${ }^{161} \mathrm{~Tb}$ dengan menggunakan kolom catridge resin Ln2 dan Ln3 masingmasing sebanyak 1, 2 dan 3 buah, radioisotop $\mathrm{Tb}$ dapat terelusi dari kolom tetapi tidak dapat terpisahkan dari matriks Gd/Tb. Jadi radioisotop Tb keluar bersamasama dengan radioisotop $\mathrm{Gd}$ seperti terlihat pada Gambar 3 dan Gambar 4. Hal ini disebabkan berdasarkan perbedaan struktur kimia yang dimiliki ketiga jenis resin tersebut seperti terlihat pada Gambar 2. Hidroksida $(\mathrm{OH})$ pada gugus fosfat yang terdapat pada resin Ln untuk mengalami kesetimbangan dinamis dengan analit dikelilingi oleh atom oksigen dengan jumlah yang lebih banyak dibandingkan pada resin Ln2 dan Ln3, maka keelektronegatifan atom oksigen pada hidroksida tersebut pada resin Ln lebih besar dibandingkan resin Ln2 dan Ln 3, sehingga awan elektron di sekitar atom hidrogen pada hidroksida akan semakin mudah ditarik oleh atom oksigen tersebut. Jadi atom hidrogen akan mudah lepas dan digantikan oleh adsobsi campuran ion analit dalam membentuk kesetimbangan dinamis dalam resin. Hal ini mengakibatkan campuran ion analit juga dapat dilepaskan dengan mudah dari resin tetapi sulit untuk dipisahkan dari campurannya oleh eluen yang sesuai pada saat elusi. Adapun pertukaran kesetimbangan yang terjadi diasumsikan sebagai berikut:

$$
\mathrm{M}^{+3}+\overline{3(\mathrm{HY})_{2}} \longleftrightarrow \overline{\mathrm{M}\left(\mathrm{HY}_{2}\right)_{3}}+3 \mathrm{H}^{+}
$$

Hal ini juga dibuktikan dari profil elusi yang diperoleh pada Gambar 3 dan Gambar 4.

Proses pemisahan radioisotop ${ }^{161} \mathrm{~Tb}$ dari matriks $\mathrm{Gd} / \mathrm{Tb}$ menggunakan kolom catridge resin Ln 2 (50-100 $\mu \mathrm{m})$ lebih lambat keluar dari kolom dibanding menggunakan kolom catridge resin Ln 3 (50-100 $\mu \mathrm{m})$. Pada Gambar 3 yaitu proses pemisahan menggunakan kolom cartridge Ln2 terlihat bahwa campuran $\mathrm{Gd} / \mathrm{Tb}$ yang tidak berhasil dipisahkan mulai ke luar dari kolom pada fraksi ke 7, sedangkan pada Gambar 4 yaitu proses pemisahan menggunakan kolom cartridge Ln3 terlihat bahwa campuran $\mathrm{Gd} / \mathrm{Tb}$ yang tidak berhasil dipisahkan langsung ke luar dari kolom pada fraksi ke 1. 

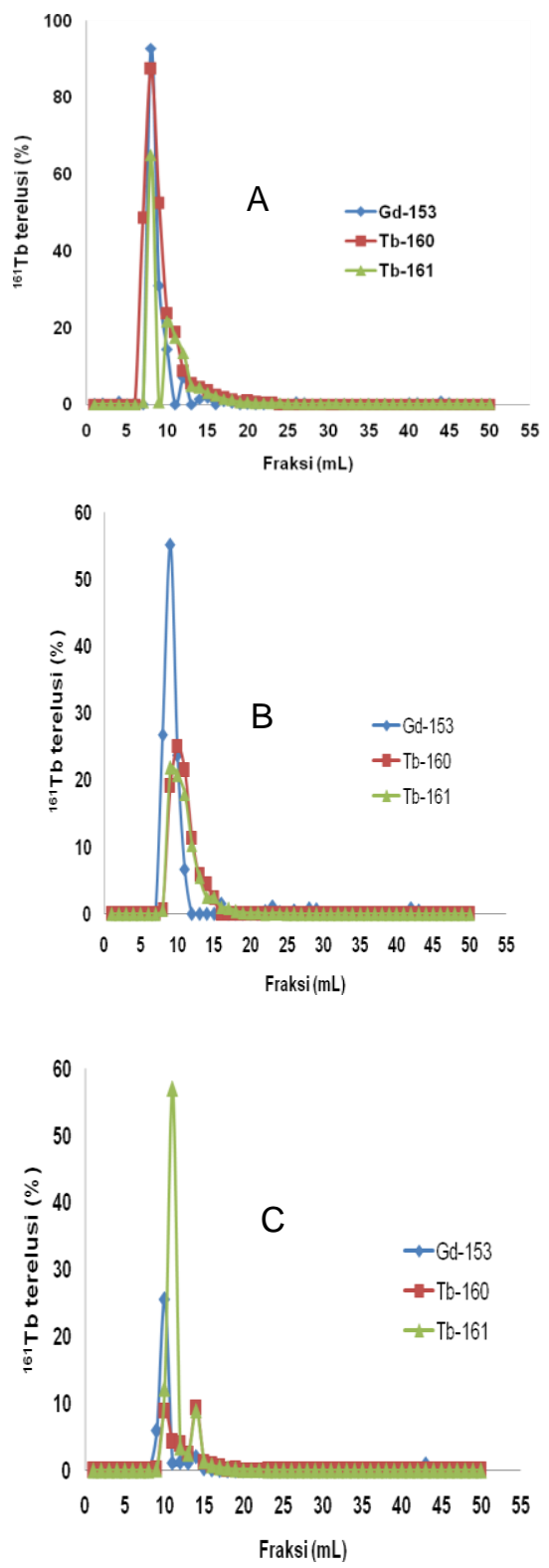

Gambar 3. Profil elusi pemisahan radioisotop ${ }^{161} \mathrm{~Tb}$ hasil iradiasi $\mathrm{Gd}_{2} \mathrm{O}_{3}$ diperkaya $\left({ }^{160} \mathrm{Gd} 98,4 \%\right)$ menggunakan kolom catridge resin $\operatorname{Ln} 2(50-100 \mu \mathrm{m}) 1$ buah (A), ditandem 2 buah $(B)$ dan ditandem 3 buah (C).

Pada Gambar 3 dan Gambar 4 juga terlihat bahwa dengan bertambahnya jumlah tandem pada kolom cartridge resin maka campuran $\mathrm{Gd} / \mathrm{Tb}$ yang tidak berhasil dipisahkan akan makin lambat ke luar dari kolom. Hal ini disebabkan jumlah resin
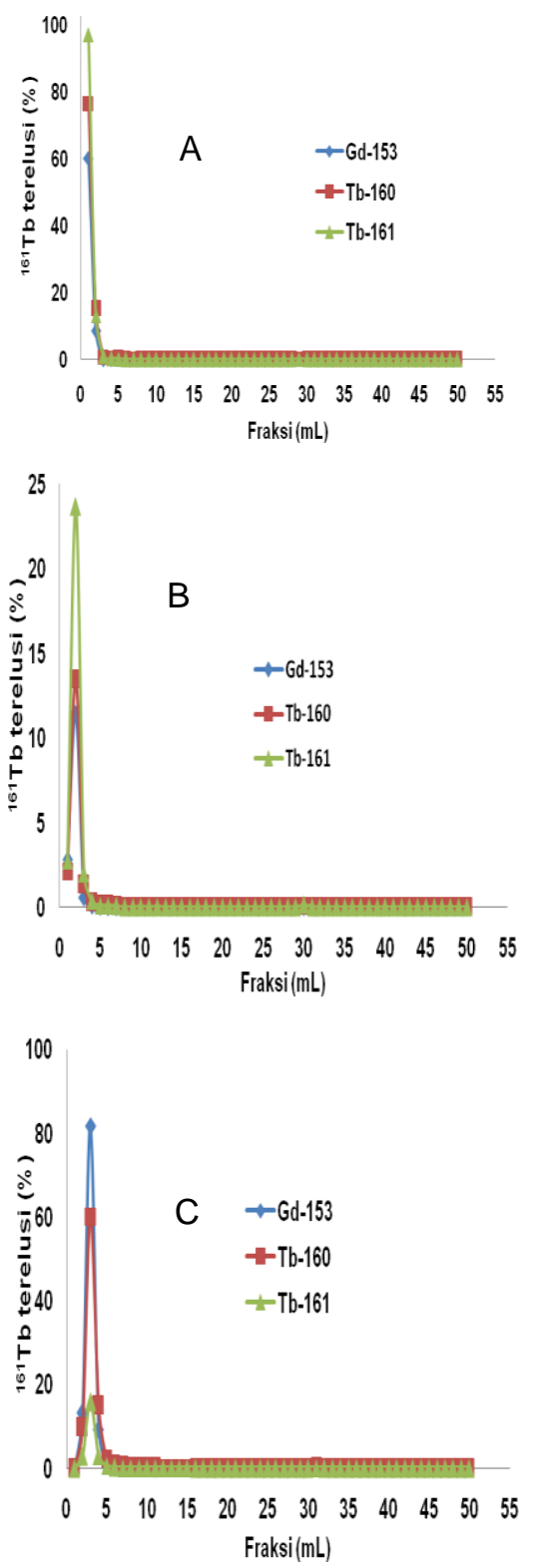

Gambar 4. Profil elusi pemisahan radioisotop ${ }^{161} \mathrm{~Tb}$ hasil iradiasi $\mathrm{Gd}_{2} \mathrm{O}_{3}$ diperkaya $\left({ }^{160} \mathrm{Gd} 98,4 \%\right)$ menggunakan kolom catridge resin $\operatorname{Ln} 3(50-100 \mu \mathrm{m}) 1$ buah $(A)$, ditandem 2 buah $(B)$ dan ditandem 3 buah $(\mathrm{C})$.

semakin bertambah sehingga analit makin sulit dikeluarkan dari kolom.

Pada penelitian ini juga diperoleh Gd recovery hasil proses pemisahan menggunakan berbagai jenis kolom catridge resin lantanida, yaitu resin Ln, Ln2 dan Ln3 masing-masing dengan ukuran partikel 50 - 
$100 \mu \mathrm{m}$ (Tabel 2). Pada Tabel 2 terlihat bahwa pemisahan radioisotop ${ }^{161} \mathrm{~Tb}$ dengan menggunakan kolom catridge resin Ln sebanyak 1, 2 dan 3 buah dengan ukuran partikel $50-100 \mu \mathrm{m}$ diperoleh $\mathrm{Gd}$ recovery yang cukup tinggi. Akan tetapi, nilai Gd recovery yang tertinggi diperoleh menggunakan kolom catridge resin Ln sebanyak 2 buah (ditandem) yaitu sebesar $97,65 \pm 0,2 \%$, sedangkan pemisahan radioisotop ${ }^{161} \mathrm{~Tb}$ dengan menggunakan kolom catridge resin Ln2 dan Ln3 masingmasing sebanyak 1, 2 dan 3 buah, Gd recovery tidak berhasil diperoleh karena walaupun radioisotop $\mathrm{Gd}$ dapat terelusi dari kolom, tetapi tidak dapat dipisahkan dari radioisotop $\mathrm{Tb}$ (radioisotop $\mathrm{Gd}$ keluar bersama-sama dengan radioisotop $\mathrm{Tb}$ ).

Selain yield pemisahan, nilai kemurnian radionuklida juga merupakan faktor yang sangat penting dari hasil pemisahan menggunakan kolom cartridge berbagai jenis resin lantanida. Nilai kemurnian radionuklida dari radioisotop ${ }^{161} \mathrm{~Tb}$ hasil pemisahan menggunakan berbagai jenis kolom catridge resin lantanida, yaitu kolom catridge resin Ln, Ln2 dan Ln3 masing-masing dengan ukuran partikel 50 - $100 \mu \mathrm{m}$ ditunjukkan pada Tabel 2. Proses pemisahan radioisotop ${ }^{161} \mathrm{~Tb}$ dengan menggunakan kolom catridge resin Ln sebanyak 1, 2 dan 3 buah dengan ukuran partikel $50-100 \mu \mathrm{m}$ diperoleh nilai kemurnian radionuklida ${ }^{161} \mathrm{~Tb}$ yang tinggi. Akan tetapi nilai kemurnian radionuklida dari radioisotop ${ }^{161} \mathrm{~Tb}$ yang tertinggi diperoleh menggunakan kolom catridge resin Ln sebanyak 2 buah (ditandem), yaitu
99,98 \pm 0,01\%. Proses pemisahan radioisotop ${ }^{161} \mathrm{~Tb}$ dengan menggunakan kolom catridge resin Ln2 dan Ln3 masingmasing sebanyak 1, 2 dan 3 buah, nilai kemurnian radionuklida dari radioisotop ${ }^{161} \mathrm{~Tb}$ yang diperoleh masih rendah yaitu mirip dengan nilai kemurnian radionuklida radioisotop ${ }^{161} \mathrm{~Tb}$ sebelum proses pemisahan yaitu sekitar $99,82 \%$. Hal ini disebabkan radioisotop $\mathrm{Tb}$ walaupun dapat terelusi dari kolom, tetapi tidak dapat dipisahkan dari radioisotop Gd.

Berdasarkan hasil yang diperoleh pada Tabel 2 menunjukkan bahwa kolom catridge resin Ln dengan ukuran partikel 50 - $100 \mu \mathrm{m}$ yang ditandem sebanyak 2 buah memiliki kriteria pemisahan yang lebih baik dibanding kedua jenis kolom catridge resin Ln lainnya, baik dari segi yield pemisahan, Gd recovery maupun kemurnian radionuklida dari radioisotop ${ }^{161} \mathrm{~Tb}$ yang dihasilkan. Dengan membandingkan hasil yang diperoleh pada Tabel 1 dan Tabel 2 menunjukkan bahwa penggunaan kolom catridge resin Ln dengan ukuran partikel 50 - $100 \mu \mathrm{m}$ yang ditandem sebanyak 2 buah dapat meningkatkan yield pemisahan serta nilai kemurnian radionuklida dari radioisotop ${ }^{161} \mathrm{~Tb}$. Di samping itu, penggunaan kolom catridge resin Ln juga lebih mudah dan cepat dalam preparasinya dibanding menggunakan kolom gelas seperti yang telah dilakukan pada penelitian sebelumnya (15), sehingga hal ini dapat meminimalkan kehilangan radioaktivitas selama proses dan menekan biaya produksi. Kemudahan dalam proses pembuatan merupakan salah satu 
kriteria yang harus dipertimbangkan dalam produksi radioisotop.

Profil elusi pemisahan radioisotop ${ }^{161} \mathrm{~Tb}$ hasil iradiasi bahan sasaran $\mathrm{Gd}_{2} \mathrm{O}_{3}$ diperkaya isotop ${ }^{160} \mathrm{Gd} 98,4 \%$ menggunakan larutan $\mathrm{HNO}_{3} 0,15 \mathrm{~N}$ (fraksi 1-6), $\mathrm{HNO}_{3} 0,8 \mathrm{~N}$ (fraksi 7-28) dan $\mathrm{HNO}_{3} 3 \mathrm{~N}$ (fraksi 29-50) ditunjukkan pada Gambar 5. Radionuklida ${ }^{153} \mathrm{Gd}$ terelusi setelah fraksi ke-10. Puncak radioaktivitas ${ }^{153} \mathrm{Gd}$ diperoleh pada fraksi 11 - 16 dengan total volume $6 \mathrm{~mL}$. Sedangkan ${ }^{161} \mathrm{~Tb}$ terelusi setelah fraksi ke-29. Puncak radioaktivitas ${ }^{161} \mathrm{~Tb}$ diperoleh pada fraksi $30-33$ dengan total volume 4 $\mathrm{mL}$. Hasil yang diperoleh menunjukkan bahwa ${ }^{161} \mathrm{~Tb}$ hasil pemisahan memiliki volume yang kecil, sehingga ${ }^{161} \mathrm{~Tb}$ dengan konsentrasi radioaktif tinggi dapat dihasilkan.

Spektrum sinar- $\gamma$ fraksi $\mathrm{Tb}$ hasil pemisahan radioisotop ${ }^{161} \mathrm{~Tb}$ dari iradiasi $\mathrm{Gd}_{2} \mathrm{O}_{3} \quad$ diperkaya $\left({ }^{160} \mathrm{Gd} \quad 98,4 \%\right)$ menggunakan kolom catridge resin Ln $\quad(50-100 \mu \mathrm{m})$ ditandem 2 buah ditunjukkan pada Gambar 6 .

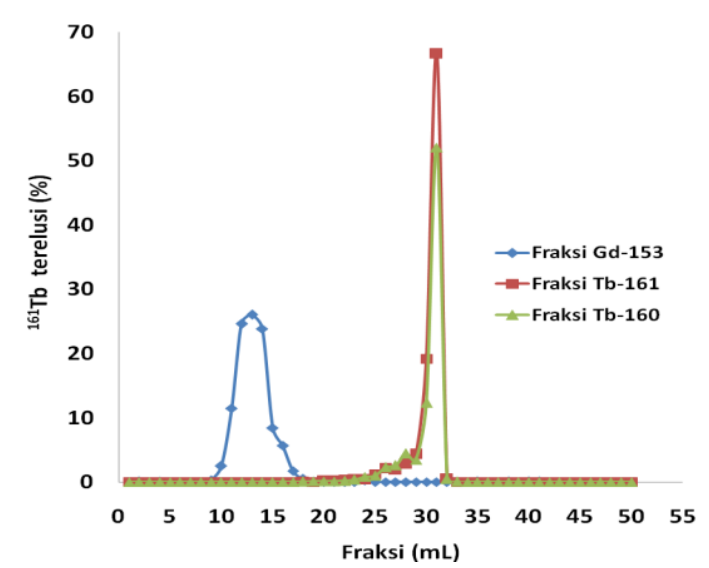

Gambar 5. Profil elusi pemisahan radioisotop ${ }_{161} \mathrm{~Tb}$ hasil iradiasi $\mathrm{Gd}_{2} \mathrm{O}_{3}$ diperkaya $\left({ }^{160} \mathrm{Gd} 98,4 \%\right)$ menggunakan kolom catridge resin $\operatorname{Ln}(50-100 \mu \mathrm{m})$ ditandem 2 buah dengan eluen $\mathrm{HNO}_{3} 0,15 \mathrm{~N} ; 0,8 \mathrm{~N}$ dan $3 \mathrm{~N}$.

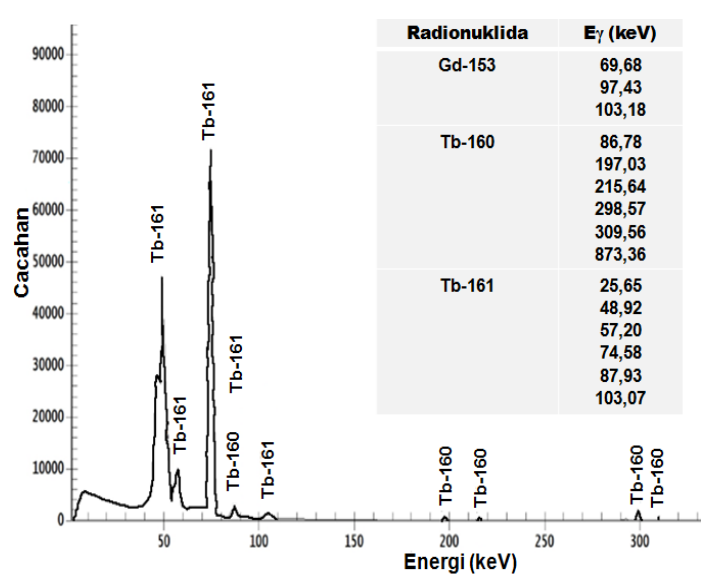

Gambar 6. Spektrum sinar-y fraksi radioisotop ${ }^{161} \mathrm{~Tb}$ hasil pemisahan menggunakan kolom catridge resin $\operatorname{Ln}(50-100 \mu \mathrm{m})$ ditandem 2 buah.

Pada Gambar 6 terlihat bahwa ${ }^{161} \mathrm{~Tb}$ dapat dipisahkan dari ${ }^{153} \mathrm{Gd}$ dengan baik. Hal ini dibuktikan dengan munculnya berbagai puncak energi gamma yang dimiliki oleh radionuklida ${ }^{161} \mathrm{~Tb}$ pada spektrum sinar$\mathrm{Y}$ yang diperoleh. Radionuklida ${ }^{161} \mathrm{~Tb}$ hasil pemisahan diperoleh dengan kemurnian radionuklida sebesar $99,98 \pm 0,01 \%$.

Produk akhir sediaan radioisotop ${ }^{161} \mathrm{~Tb}$ yang dihasilkan diharapkan berada dalam bentuk kimia ${ }^{161} \mathrm{TbCl}_{3}$ (7). Kemurnian radiokimia larutan radioisotop ${ }^{161} \mathrm{TbCl}_{3}$ ditentukan dengan metode kromatografi kertas. Sistem kromatografi kertas yang digunakan pada penelitian ini mengacu pada sistem kromatografi kertas yang telah diperoleh pada penelitian sebelumnya dalam penentuan kemurnian radiokimia larutan radioisotop ${ }^{161} \mathrm{TbCl}_{3}$ hasil iradiasi bahan sasaran $\mathrm{Gd}_{2} \mathrm{O}_{3}$ alam yaitu menggunakan kertas kromatografi Whatman $3 \mathrm{MM}(2 \times 10 \mathrm{~cm})$ sebagai fase diam serta larutan asam asetat $50 \%$ sebagai fase gerak (18). Sistem kromatografi kertas yang digunakan seperti terlihat pada Gambar 7 dapat memisahkan senyawa ${ }^{161} \mathrm{TbCl}_{3}$ dari 
senyawa ${ }^{161} \mathrm{~Tb}(\mathrm{OH})_{3}$ sebagai pengotor radiokimianya yang mungkin berada di dalam larutan radioisotop tersebut. Penentuan kemurnian radiokimia larutan radioisotop ${ }^{161} \mathrm{TbCl}_{3}$ menggunakan sistem kromatografi kertas Whatman $3 \mathrm{MM}$ dengan eluen asam asetat $50 \%$ menghasilkan puncak tunggal, yaitu senyawa ${ }^{161} \mathrm{TbCl}_{3}$ yang bermigrasi ke arah fase gerak dengan $\mathrm{Rf}=0,8-0,9$. Hasil penentuan kemurnian radiokimia radioisotop ${ }^{161} \mathrm{~Tb}$ menggunakan sistem kromatografi tersebut diperoleh produk akhir ${ }^{161} \mathrm{~Tb}$ dalam bentuk senyawa kimia ${ }^{161} \mathrm{TbCl}_{3}$ dengan kemurnian radiokimia sebesar $99,92 \pm 0,2 \%$.

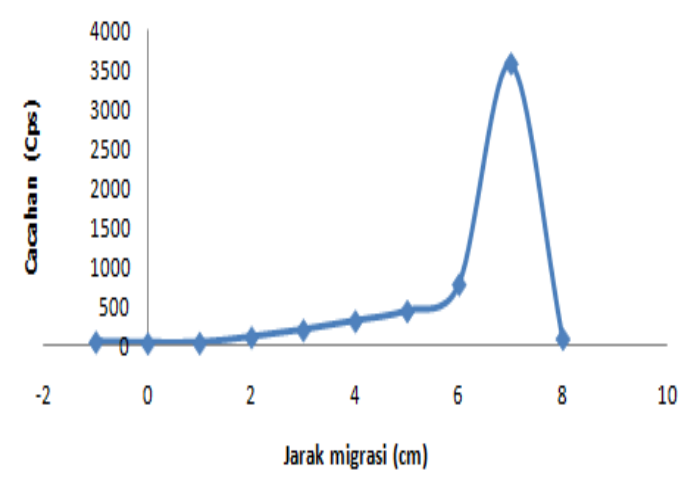

Gambar 7. Kromatogram ${ }^{161} \mathrm{TbCl}_{3}$ menggunakan fase diam kertas kromatografi Whatman 3 MM dan fase gerak eluen asam asetat $50 \%$.

\section{KESIMPULAN}

Peningkatan yield pemisahan radioisotop ${ }^{161} \mathrm{~Tb}$ berhasil diperoleh menggunakan kolom catridge resin Ln $(50-100 \mu \mathrm{m})$ dengan cara ditandem 2 buah. Hasil pemisahan radioisotop ${ }^{161} \mathrm{~Tb}$ memiliki yield sebesar $100 \pm 0,1 \%$ dan $\mathrm{Gd}$ recovery sebesar $97,65 \pm 0,2 \%$. Fraksi ${ }^{161} \mathrm{~Tb}$ hasil pemisahan memiliki kemurnian radionuklida 99,98 $\pm 0,01 \%$. Produk akhir larutan radioisotop ${ }^{161} \mathrm{~Tb}$ yang diperoleh berada dalam bentuk senyawa ${ }^{161} \mathrm{TbCl}_{3}$ dengan kemurnian radiokimia sebesar 99,92 $\pm 0,2 \%$.

\section{UCAPAN TERIMAKASIH}

Penelitian ini didanai oleh DIPA Pusat Sains dan Teknologi Nuklir Terapan Badan Tenaga Nuklir Nasional. Penulis mengucapkan terima kasih kepada mahasiswa Kerja Praktek dari Universitas Pendidikan Indonesia, Universitas Negeri Malang dan Universitas Islam Negeri Sunan Gunung Djati Bandung yang telah membantu dalam pelaksanaan penelitian ini.

\section{DAFTAR PUSTAKA}

1. Zhang L, Chen $H$, Wang L, Liu T, Yeh J, Lu G, Yang L, Mao H. Delivery of therapeutic radioisotopes using nano particle platforms: Potential benefit in systemic radiation therapy. Nanotech Sci Appl 2010;3:159-70.

2. Luo TY, Tang IC, Wu YL, Hsu KL, Liu SW, Kung HC, Lai PS, Lin WJ.

Evaluating the potential of ${ }^{188} \mathrm{Re}$ SOCTA-trastuzumab as a new radioimmunoagent for breast cancer treatment. J Nucl Med Biol 2009;36:81-8.

3. Saranti E, Study of radiolabeling of chemically modified bombesin. Thesis. Charles University in Parague. 2013:1-52.

4. Pillai MRA, Dash A, Knapp FF. Rhenium-188: Availability from the ${ }^{188 \mathrm{~W} / 188} \mathrm{Re}$ Generator and status of current applications. Curr Radiopharm 2012;5:228-43.

5. Ersahin D, Doddamane I, Cheng D. 
Targeted radionuclide therapy.

Cancers 2011;3:3838-55.

6. Sadeghi M, Enferadi M, Shirazi A.

External and internal radiation therapy: Past and future directions. J Canc Res Ther 2010;6(3):239-48.

7. Lehenberger S, Barkhausen C, Cohrs S, Fischer E, Grunberg J, Hohn A, Koster U, Schibli R, Turler A, Zhernosekov K. The low energy $\beta$ - and electron emitter ${ }^{161} \mathrm{~Tb}$ as an alternative to ${ }^{177} \mathrm{Lu}$ for targeted radionuclide therapy. J Nucl Med Biol 2011;38:91724.

8. Muller C, Reber J, Haller S, Dorrer H, Koster U, Johnston K, Zhernosekov K, Turler A, Schibli R. Folate receptor targeted alpha therapy using terbium149. Pharmaceuticals 2014;7:353-65.

9. Roesch F. Radiolanthanides in endoradiotherapy: An overview. Radiochim Acta 2007;95:303-11.

10. Lehenberger SM, Evaluation and application of the low energy electron emitter ${ }^{161} \mathrm{~Tb}$, Dissertation 2010:1-140.

11. Muller $\mathrm{C}$, Zhernosekov K, Koster U, Johnston K, Dorrer H, Hohn A, Walt NT, Turler A, Schibli R. $A$ unique matched quadruplet of terbium radioisotopes for $\mathrm{PET}$ and SPECT and for $\alpha$ - and $\beta$ - radionuclide therapy: An in vivo proofof-concept study with a new receptortargeted folate derivative. J Nucl Med 2012;53: 1-9.
12. Roesch F. Therapeutic radiolanthanides and the dosimetry by using PET. Seventh International Conference on Nuclear and Radiochemistry, Hungary, 24-29 August 2008.

13. Aziz A, Artha WT. Radiochemical separation of ${ }^{161} \mathrm{~Tb}$ from $\mathrm{Gd} / \mathrm{Tb}$ matrix using Ln resin column. Indones J Chem 2016;16(3):283-8.

14. Guzman FM, Morales JA, Chapter 5, Radioisotope production for health applications, 2010.

15. Aziz A, Nuryadin R. Pemisahan radioisotop ${ }^{161} \mathrm{~Tb}$ hasil iradiasi bahan sasaran gadolinium oksida diperkaya isotop ${ }^{160} \mathrm{Gd}$ menggunakan metode kromatografi ekstraksi. Jurnal Sains dan Teknologi Nuklir Indonesia 2016;17(2)83-96.

16. Guzman FM, Salinas EJ. Separation of micro-macrocomponent system: ${ }^{149} \mathrm{Pm}-\mathrm{Nd},{ }^{161} \mathrm{~Tb}-\mathrm{Gd},{ }^{166} \mathrm{Ho}-\mathrm{Dy}$ and ${ }^{177} \mathrm{Lu}-\mathrm{Yb}$ by extraction chromatography. J Mex Chem Soc 2015;59(2):143-50.

17. Guzman FM, Barreiro FJ, Salinas EJ, Trevino ALV. Radiolanthanides device production. World J Nucl Scie Tech 2015;5:111-9.

18. Aziz A, Suherman N. Karakterisasi fisiko-kimia radioisotop terbium-161klorida ( ${ }^{161} \mathrm{TbCl}_{3}$ ) hasil iradiasi bahan sasaran gadolinium oksida alam. J Iptek Nuklir Ganendra 2015;18(1):45-54. 